\title{
Nursing team knowledge on care for patients with fungating wounds
}

\author{
Conhecimento da equipe de enfermagem sobre cuidados com pacientes com feridas neoplásicas \\ Conocimiento del equipo de enfermería sobre cuidados con pacientes con úlceras neoplásicas
}

Fernanda Mateus Queiroz Schmidt'
ORCID: 0000-0002-2454-6548

Flávia Firmino"

ORCID: 0000-0002-9285-4614

Nariman de Felício Bortucan Lenza"' ORCID: 0000-0001-8902-4479

Vera Lúcia Conceição de Gouveia Santosiv ORCID: 0000-0002-1288-5761

'Instituto Federal de Educação, Ciência e Tecnologia do Sul de Minas Gerais. Passos, Minas Gerais, Brazil. "Instituto Nacional do Câncer. Rio de Janeiro, Rio de Janeiro, Brazil.

I'IFaculdade Atenas. Passos, Minas Gerais, Brazil. "Universidade de São Paulo. São Paulo, São Paulo, Brazil.

How to cite this article: Schmidt FMQ, Firmino F, Lenza NFB, Santos VLCG. Nursing team knowledge on patients care with fungating wounds. Rev Bras Enferm. 2020;73(1):e20170738. doi: http://dx.doi.org/10.1590/0034-7167-2017-0738

\section{Corresponding Author:}

Fernanda Mateus Queiroz Schmidt E-mail: fernandamqueiroz@yahoo.com.br

EDITOR IN CHIEF: Dulce Aparecida Barbosa ASSOCIATE EDITOR: Margarida Vieira

Submission: 08-05-2018

Approval: 20-12-2018

\section{ABSTRACT}

Objective: to evaluate the nursing team knowledge of a cancer hospital on care for patients with Malignant Fungating Wounds (MFW) and to analyze associated sociodemographic and educational factors. Method: an observational and cross-sectional study, conducted between September and October 2015, after approval by the Research Ethics Committee. A questionnaire was applied containing sociodemographic, educational and related components to the accomplishment of dressings, dressings choice and orientation. Data were analyzed by using Chi-square, Fisher's exact test, Student's t-Test and Pearson's correlation. Results: 37 professionals participated in the study, most of whom were technicians (56.8\%), women (91.9\%) and with a mean age of 32 years. The professionals presented $56.5 \%$ of correct answers. There were no statistically significant associations between sociodemographic/educational variables and number of correct answers. Conclusion: there was a lack of important knowledge about care for patients with MFW which should guide strategies for the oncology staff training.

Descriptors: Wounds and Injuries; Neoplasms; Nursing Care; Oncology Nursing; Knowledge Management.

\section{RESUMO}

Objetivo: avaliar o conhecimento da equipe de enfermagem de um hospital oncológico sobre o cuidado de pacientes com Feridas Neoplásicas Malignas (FNM) e analisar fatores sociodemográficos e educacionais associados. Método: estudo observacional e transversal, realizado entre setembro e outubro de 2015, após aprovação por Comitê de Ética em Pesquisa. Foi aplicado questionário contendo componentes sociodemográficos, educacionais e relacionados à realização de curativos, escolha de coberturas e orientação. Os dados foram analisados por meio do Teste Qui-Quadrado, Exato de Fisher, Teste $t$ de Student e correlação de Pearson. Resultados: participaram do estudo 37 profissonais, sendo a maioria técnicos $(56,8 \%)$, mulheres $(91,9 \%)$ e com idade média de 32 anos. Os profissionais apresentaram $56,5 \%$ de acertos. Não houve associações estatisticamente significativas entre variáveis sociodemográficas/educacionais e número de acertos. Conclusão: observou-se déficit de conhecimentos importantes sobre o cuidado de pacientes com FNM, o que deve nortear estratégias para capacitação das equipes atuantes em Oncologia.

Descritores: Ferimentos e Lesões; Neoplasias; Cuidados de Enfermagem; Enfermagem Oncológica; Gestão do Conhecimento.

\section{RESUMEN}

Objetivo: evaluar el conocimiento del equipo de enfermería de un hospital oncológico sobre el cuidado de pacientes con Úlceras Neoplásicas Malignas (UNM) y analizar factores sociodemográficos y educativos asociados. Método: estudio observacional y transversal, realizado entre septiembre y octubre de 2015, tras la aprobación por el Comité de Ética en Investigación. Se aplicó un cuestionario que contenía componentes sociodemográficos, educativos y relacionados con la realización de curativos, elección de coberturas y orientación. Los datos fueron analizados a través del Test Qui-Cuadrado, Exacto de Fisher, Test t de Student y correlación de Pearson. Resultados: en el estudio 37 profesionales, siendo la mayoría técnicos $(56,8 \%)$, mujeres $(91,9 \%$ ) y con edad media de 32 años. Los profesionales presentaron un $56,5 \%$ de aciertos. No hubo asociaciones estadísticamente significativas entre variables sociodemográficas/educativas y número de aciertos. Conclusión: se observó déficit de conocimientos importantes sobre el cuidado de pacientes con UNM, lo que debió orientar estrategias para capacitación de los equipos actuantes en Oncología.

Descriptores: Heridas y Lesiones; Neoplasias; Cuidados de Enfermería; Enfermería Oncológica; Gestión del Conocimiento. 


\section{INTRODUCTION}

Public health policies development in oncology, such as the inclusion of Palliative Care (PC) as a comprehensive part of health care programs ${ }^{(1)}$ and the increase in the survival time of people affected by cancer, have brought greater visibility to care practices in nursing in the different domains of the process of falling ill and dying of cancer ${ }^{(2)}$. In particular, in the domains of advanced, uncontrolled and with no prospect of cure cancer, signs and symptoms malignant neoplasms control and the improvement of quality of life are the most realistic therapeutic goals for all professionals who make up the health team ${ }^{(3)}$. In this perspective, Malignant Fungating Wounds (MFW) care emerges as one of the current research objects of nursing worldwide, based on the health needs of a population that lives with incurable cancer ${ }^{(2,4)}$.

Conceptually, these wounds are made up by the infiltration of malignant cells into the skin. They may be due to primary or metastatic cancer. They begin as an intact nodule and, if the underlying disease does not respond to treatment, these wounds may become tumor masses that deform the body and lead to infection and necrosis, within a framework of organic degeneration that composes the signs and symptoms that are characteristic, such as pain, bleeding, abundant secretion, and foul odor ${ }^{(5)}$.

There is no default denomination for the term. In the international context, the term "malignant wounds" or "malignant fungating wounds" has been adopted that in free translation into Portuguese would be "feridas malignas" and "feridas malignas fungosas"(2,6-13). In Brazil, terms such as tumor wound, fungating wound, oncological wound, among others have been adopted ${ }^{(14-16)}$. In this study, the term Malignant Fungating Wound was used to clearly indicate that the wound is due to a malignant neoplasm, since neoplasia can also express benign tumors formation ${ }^{(17)}$.

In addition to tissue damage caused by MFW formation itself, the damage imposed on the whole skin around the wound due to the exudate's characteristics, which contributes to cause dermatitis associated with moisture ${ }^{(8)}$ and other complications, such as fistulas formation and/or larvae (myiasis) infestation, especially in tropical countries $^{(2,9)}$. When cancer cure becomes an unrealistic goal, MFW will be the main source of stress, distress and distress for the patient and his family and/or caregivers, including health professionals $s^{(4,6-8)}$.

Not all cancer patients have cutaneous MFW. In the international literature, it is estimated that up to $15 \%$ of cancer patients develop MFW in the most advanced stage of the disease ${ }^{(11)}$. In Brazil, considering that for the biennium 2018/2019 the Instituto Nacional do Câncer (National Cancer Institute) estimated 600,000 new cases/year of cancer; 90,000 people will be able to develop MFW annually ${ }^{(18)}$. Furthermore, due to the high incidence of cancer in our country and the increase of health services in oncology in general and/or specialized hospitals, it is inferred that more and more nursing professionals will come into contact with cancer people and affected by MFW.

Skin, breast, head and neck, and gynecological cancer are among the main types of MFW generators ${ }^{(2)}$. This type of wounds has a devastating impact on the daily routine of patients. Researches conducted by European nurses who investigated the experience of patients, family members, caregivers and nurses living with an MFW showed that the physical signs and symptoms of MFW are disturbing and impoverish the patients' quality of life: the wound becomes more and more demanding of the patient's time and his relative-caregiver; life revolves around the wound and the fear related to it is the most lived feeling. Nevertheless, it is a neglected aspect of care in cancer in nursing practice ${ }^{(8-10)}$.

Other research conducted by the same group of European nurses specifically investigated the experience of family caregivers and showed that the MFW of a loved one causes extreme physical and psychological distress. Moreover, it takes most of the time, the familiar realizes that the physical changes resulting from MFW result in changes in body image, depression and social isolation of that loved one. For them, caring for MFW"is the most difficult of all"(11).

Researches conducted by Taiwanese ${ }^{(12)}$ and English ${ }^{(13)}$ nurses investigating the association of MFW and quality of life, and using patient interviews and literature review, respectively, have demonstrated that quality of life is deteriorated in an overwhelming way by the presence of the wound and lack of control, above all, physical symptoms. Physical symptoms impact on all other dimensions of life: social, psychological and spiritual. Taiwanese nurses say that "these wounds pose significant challenges for nurses working in the field of cancer". However, these same nurses "responsible for improving the level of care" to patients affected by these impactful wounds are not able to perform this essential task for their patients. They conclude that evaluation and correct management of symptoms increase the quality of life of patients and suggest elaboration of research that identifies if the competence of nursing has a direct impact on the quality of life of patients assisted ${ }^{(12)}$.

Research by English nurses endorses these results and recommends that patients use information to reduce anxiety and stress. Nurses are advised to make use of the literature on the subject. There is opposition to health organizations that they should care about educational questions and technical training for this topic ${ }^{(13)}$.

From 2003 to 2014, five studies ${ }^{(7-8,10,16,19)}$ sought to identify practices and experiences of nurses on this topic, two of them being developed in Brazil among nurses of a specialized oncology service $^{(19)}$ and nurses in the Family Health Strategy ${ }^{(16)}$. These studies corroborate with the results of the researches of the Taiwanese and English nurses, that is, they point out deficits of knowledge of Brazilian nurses, oncology experts and generalists, in relation to care for people affected by cancer that generate MFW.

Considering the composition of the Brazilian nursing team and highlighting the development of this topic in Brazil, the motivation was given to develop this study involving nursing technicians and nurses who work in oncology.

\section{OBJECTIVE}

To evaluate the knowledge about care for patients with MFW of nursing team members in a hospital specialized in treatment of cancer; and analyze demographic and educational factors associated.

\section{METHOD}

\section{Ethical aspects}

The research project was analyzed and approved by the Research Ethics Committee (via Plataforma Brasil), and all the 
ethical precepts required by Resolution 466 of December 12, 2012 of the Brazilian Health Board ${ }^{(20)}$.

\section{Design, place of study, and period}

This is a cross-sectional and quantitative observational study developed at a hospital specialized in cancer and referral diseases for the municipalities of the Southwest of Minas Gerais State, from September to October 2015.

\section{Population or sample; inclusion and exclusion criteria}

The study population consisted of nursing professionals working in the fields of the institution: Radiotherapy, Chemotherapy, Ambulatory, and Adult and Child Inpatient Unit. During data collection period, the professional staff of the nursing team that was directly involved in care for cancer patients in the hospital was composed of 18 nurses and 23 nursing technicians, totaling 41 nursing professionals in said fields.

There was inclusion in this study of all nursing professionals who were willing to answer the questionnaire and who agreed to voluntarily participate in the research, after clarification and by signing the Free and Informed Consent Form (FICF). Those who were on vacation, leave or work leave during data collection period were excluded.

\section{Study protocol}

A questionnaire, for data collection, was developed by the researchers and composed of sociodemographic data, educational training and 11 objective questions divided into two dimensions of knowledge about MFW: specific technical knowledge of dressing practice; and theoretical concepts about development and progression of wounds.

The variables corresponding to the sociodemographic data were: gender, age, marital status, work field in the hospital, profession, training time, oncology work time, another academic training, prior specific training on wounds (special training courses on the subject, specific stages for wound care, training courses, and improvement) and participation in scientific events related to the "wounds" theme in the last five years (conferences, symposia, seminars, congresses, lectures). In the "specific technical knowledge of dressing practice" dimension, the following components were addressed: clean or sterile technique use for topical home treatment, bleeding prevention procedures, bleeding, odor, and exudate control, infection identification, myiasis infestation, choice of adequate coverings considering the products available in hospital practice (activated charcoal, hydrocolloid powder, antiseptics, etc.). In the "theoretical concepts about development and progression of wounds" dimension, the following components were addressed: MFW classification and objectives of the dressings necessary for this type of wound.

As there is no validated instrument in the literature to evaluate knowledge of professionals about MFW care, the questionnaire used in this research was based on recommendations proposed by national guidelines of the Instituto Nacional de Câncer José Alencar Gomes da Silva (National Cancer Institute José Alencar
Gomes da Silva) - INCA and the recommendations of the A.C. Camargo Cancer Center ${ }^{(9,21)}$. These are literatures dated respectively from the years 2009 and 2011, whose guidelines remain in force. After reviewing these recommendations, two researchers (a stomatologist and an oncology expert) elaborated the questions and submitted them to analysis and opinion of two other nurses specialized in stomatology and PC in oncology, and with expertise in MFW. It was expected that components of the"specific technical knowledge of dressing practice" dimension had more right answers: clean sterile technique use; bleeding control and prevention, odor control, non-stimulating healing covers use. These are the minimum knowledge to perform quality nursing care for patients affected by MFW, as observed by the nurses who evaluated the questionnaire content.

Data collection was performed during September and October 2015, in the referred hospital. At dates and times previously scheduled with the nursing coordinator, nursing team members were approached in their fields and invited to participate in the study; the purpose of the research was explained, voluntary nature of participation and clarification of doubts. Upon acceptance of the participant, the FICF was presented for signature. With the FICF's signature, a copy of it was delivered to the research participant and then the printed questionnaire. Participants responded individually, in their work fields, soon after the delivery by the researcher and in his presence. After self-completion, the participant placed the questionnaire, without identification, in a brown envelope offered by the researcher, thus anonymity guaranteeing.

\section{Analysis of results}

After collection, the data were entered in a spreadsheet (Microsoft Excel 2010) by using the double typing technique for further analysis of the results. The data were analyzed through descriptive statistics, with simple frequency measurements. The data were tabulated and presented in tables. The variables related to sociodemographic characteristics were summarized and presented descriptively by means of absolute and relative frequency. For numerical variables, means values, medians and Standard Deviations. In the evaluation of the correct answers, it was considered a grade 1 for those who scored and grade zero for who missed or indicated the "I do not know" option in each of the 11 questions that constituted the questionnaire. For association between the "professional category of nursing" variable and answers in the questions of knowledge test, the Chi-Square or Fisher's Exact Tests were used. The Student's t-test and the Pearson's correlation coefficient were used to verify the relationship between mean scores of their sum in the eleven items of the knowledge test and sociodemographic and educational variables. Continuous variables were presented in scatter plots. Analyzes were performed using the statistical program $R$ ( $R$ version 3.5.1 ( 2018). In all statistical tests, the significance level adopted was $5 \%(p \leq 0.05)$.

\section{RESULTS}

Of the 41 nursing professionals working at the hospital, 37 participated in the study; two employees were on vacation during 
the collection period and the non-response rate was two professionals who refused to participate in the study. All participants answered all the questions in the questionnaire, so there were no blank questions. The participation rate in the study was $90.2 \%$ of the population.

Predominantly, the sample was characterized by nursing technicians (56.8\%), women (91.9\%), mean age 32 years (SD: 8.2 ), attending inpatient units (73\%) and with mean training of 7.5 years, mean oncology work time of 4.6 years. Just over half of the professionals (54.1\%) participated in events related to the "wounds" theme in the last five years. Minorities have another academic training (16.2\%) and training in the area of wounds (35.1\%), as shown in Table 1.

The results obtained for the answers to the questions of the technical-specific knowledge test on MFW are presented in Table 2 , with absolute and relative numbers of the response options, divided by professional category.

Table 1 - Distribution of research participants according to sociodemographic and educational characteristics, Passos, Minas Gerais, Brazil, 2015

\begin{tabular}{|c|c|c|c|c|c|}
\hline \multicolumn{3}{|l|}{ Characteristcs } & \multicolumn{2}{|l|}{$\mathbf{n}$} & \multirow{2}{*}{$\begin{array}{c}\% \\
91.9 \\
8.1\end{array}$} \\
\hline Gender & $\begin{array}{l}\text { Female } \\
\text { Male }\end{array}$ & & $\begin{array}{c}34 \\
3\end{array}$ & & \\
\hline Marital Status & $\begin{array}{l}\text { Single } \\
\text { Marrie } \\
\text { Divorc } \\
\text { Stable }\end{array}$ & ion & $\begin{array}{c}19 \\
14 \\
2 \\
2\end{array}$ & & $\begin{array}{c}51.4 \\
37.8 \\
5.4 \\
5.4\end{array}$ \\
\hline Work Field & $\begin{array}{l}\text { Inpatie } \\
\text { Chemo } \\
\text { Radiot } \\
\text { Ambul }\end{array}$ & $\begin{array}{l}\text { Unit } \\
\text { erapy } \\
\text { rapy } \\
\text { ory }\end{array}$ & $\begin{array}{c}27 \\
8 \\
1 \\
1\end{array}$ & & $\begin{array}{c}73.0 \\
21.6 \\
2.7 \\
2.7\end{array}$ \\
\hline Profession & $\begin{array}{l}\text { Nursin } \\
\text { Nurse }\end{array}$ & ech. & $\begin{array}{l}21 \\
16\end{array}$ & & $\begin{array}{l}56.8 \\
43.2\end{array}$ \\
\hline Another Academic Training & $\begin{array}{l}\text { No } \\
\text { Yes }\end{array}$ & & $\begin{array}{c}31 \\
6\end{array}$ & & $\begin{array}{l}83.8 \\
16.2\end{array}$ \\
\hline Wounds Training & $\begin{array}{l}\text { No } \\
\text { Yes }\end{array}$ & & $\begin{array}{l}24 \\
13\end{array}$ & & $\begin{array}{l}64.9 \\
35.1\end{array}$ \\
\hline Participation in Events about Wounds in the Last 5 years & $\begin{array}{l}\text { Yes } \\
\text { No }\end{array}$ & & $\begin{array}{l}20 \\
17\end{array}$ & & $\begin{array}{l}54.1 \\
45.9\end{array}$ \\
\hline Characteristics & Mean & Standard Deviation & Median & Minimum value & Maximum value \\
\hline $\begin{array}{l}\text { Age (years) } \\
\text { Training Time (years) } \\
\text { Oncology Work Time (years) }\end{array}$ & $\begin{array}{l}32.5 \\
7.5 \\
4.6\end{array}$ & $\begin{array}{l}8.2 \\
5.1 \\
2.2\end{array}$ & $\begin{array}{l}30.0 \\
6.0 \\
5.0\end{array}$ & $\begin{array}{c}23 \\
2 \\
1\end{array}$ & $\begin{array}{l}57 \\
22 \\
12\end{array}$ \\
\hline
\end{tabular}

Table 2 - Comparative performance of nurses and nursing technicians in the questions of the knowledge test on Malignant Fungating Wounds care, Passos, Minas Gerais, Brazil, 2015

\begin{tabular}{|c|c|c|c|c|c|c|c|c|c|c|c|c|c|}
\hline \multirow{3}{*}{ Question } & \multicolumn{6}{|c|}{$\begin{array}{l}\text { Nursing Technicians } \\
\qquad(\mathbf{n}=21)\end{array}$} & \multicolumn{6}{|c|}{$\begin{array}{l}\text { Nurses } \\
(n=16)\end{array}$} & \multirow{3}{*}{$\begin{array}{c}p \\
\text { value }\end{array}$} \\
\hline & \multicolumn{2}{|c|}{ Scores } & \multicolumn{2}{|c|}{ Errors } & \multicolumn{2}{|c|}{$\begin{array}{l}\text { I do not } \\
\text { know }\end{array}$} & \multicolumn{2}{|c|}{ Scores } & \multicolumn{2}{|c|}{ Errors } & \multicolumn{2}{|c|}{$\begin{array}{l}\text { I do not } \\
\text { know }\end{array}$} & \\
\hline & $\boldsymbol{f}$ & $\%$ & $f$ & $\%$ & $\boldsymbol{f}$ & $\%$ & $f$ & $\%$ & $f$ & $\%$ & $\boldsymbol{f}$ & $\%$ & \\
\hline 1 - Home wound dressing technique (clean $x$ sterile technique) & 3 & 14.3 & 16 & 76.2 & 2 & 9.5 & 3 & 18.8 & 11 & 68.7 & 2 & 12.5 & $1.00 *$ \\
\hline 2 - Conduct of the nursing team in case of wound bleeding & 9 & 42.9 & 11 & 52.4 & 1 & 4.7 & 9 & 56.3 & 6 & 37.5 & 1 & 6.2 & $0.42^{* *}$ \\
\hline 3 - Purpose of dressing for fungating wounds & 7 & 33.4 & 10 & 47.6 & 4 & 19 & 10 & 62.5 & 2 & 12.5 & 4 & 25 & $0.07^{* *}$ \\
\hline $\begin{array}{l}4 \text { - Purpose of dressing and signs and symptoms control: exudate, bleeding, } \\
\text { odor, pain, and infection }\end{array}$ & 15 & 71.4 & 2 & 9.6 & 4 & 19 & 14 & 87.5 & 2 & 12.5 & - & - & $0.42^{*}$ \\
\hline 5 - Bleeding prevention & 13 & 61.9 & 8 & 38.1 & - & - & 13 & 81.3 & 3 & 18.7 & - & - & $0.28^{*}$ \\
\hline 6 - Causes of myiasis & 21 & 100 & - & - & - & - & 16 & 100 & - & & - & - & $1.00^{* *}$ \\
\hline 7 - Topical odor control therapy & 4 & 19 & 17 & 81 & - & - & 6 & 37.5 & 10 & 62.5 & - & - & $0.27^{*}$ \\
\hline 8 - Signs of wound infection & 13 & 61.9 & 8 & 38.1 & - & - & 13 & 81.3 & 3 & 18.7 & - & - & $0.28^{*}$ \\
\hline 9 - Exudate control & 15 & 71.4 & 6 & 28.6 & - & - & 14 & 87.5 & 2 & 12.5 & - & - & $0.42^{*}$ \\
\hline 10 - Classification of fungating wounds & 13 & 61.9 & - & - & 8 & 38.1 & 4 & 25 & 3 & 18.7 & 9 & 56.3 & $0.03^{*}$ \\
\hline $\begin{array}{l}11 \text { - Coverings and dressings use that do not stimulate healing and growth of } \\
\text { new cells }\end{array}$ & 8 & 38.1 & 4 & 19 & 9 & 42.9 & 7 & 43.8 & 7 & 43.7 & 2 & 12.5 & $0.73^{* *}$ \\
\hline
\end{tabular}

Note: $p$ - Descriptive level of the Fisher's Exact Test* or Pearson's Chi-Square Test**. 
Table 2 shows that the variation of correct answers in each question was from $14.3 \%$ to $71.4 \%$ among nursing technicians and from $18.8 \%$ to $87.5 \%$ among nurses, disregarding the knowledge about the cause of myiasis (question 6). Likewise, error ranged from $9.6 \%$ to $81 \%$ and from $12.5 \%$ to $62.5 \%$, respectively. Regarding the "I do not know" alternative, there was a variation from $4.7 \%$ to $42.9 \%$ among nursing technicians and from $6.2 \%$ to $56.3 \%$ among nurses.

In the "nursing technicians" category, five questions had the highest success rate: those related to the objective and symptom control through dressing (question 4), and exudate control (question 9), with 71.4 (question 5), signs of wound infection (question 8) and classification and staging (question 10), with $61.9 \%$ of scores in each. Like nurses, nursing technicians presented $100 \%$ correct answers to the question 6 - causes of myiasis.

For the group of nurses, a score success profile was observed: $87.5 \%$ for question 4 and question $9 ; 81.3 \%$ for question 5 and question 8 , with the following difference: nurses had a higher frequency of correctness for question 3, which focused on healing and dressing of the MFW, where $62.5 \%$ of the nurses were correct and $37.5 \%$ answered correctly (adding error indexes and answer option: "I do not know"). In the group of technicians, the proportion of correct answers was $33.4 \%$ and that of errors $66.6 \%$ (adding error indexes and answer option:"I do not know").

Another important difference was wounds classification (question 10). The "nursing technicians" category obtained a greater number of correct answers than the nurses. Only this question presented a statistically significant difference between the groups $(p=0.03)$. This was the fifth most frequent question in the group of nursing technicians.

Regarding errors, in the group of nursing technicians, the clean versus sterile technique use (question 1) presented $76.2 \%$ of errors, but when added to the ones that indicated the option "do not know", the proportion of $85.7 \%$ knowledge deficit. For odor control (question 7), the highest frequency of errors (81\%) was observed, with no respondents who pointed to the "do not know" question. The third question with the highest error rate concerns the goal of performing a dressing in MFW, with the goal of healing (question 3), where $66.6 \%$ of the technicians made a mistake (adding error indexes and response options: "I do not know"). The fourth question with the highest frequency of errors concerns knowledge about cell growth stimulating coverings and dressings use in malignant tumor tissue (question 11 ), where $61.9 \%$ of the nursing technicians presented knowledge deficits (adding error rates and answer option: "I do not know"). The fifth question with the highest frequency of error in this professional category was the question that investigated the knowledge about the nursing team's conduct in the case of MFW bleeding. $57.1 \%$ of the nursing technicians presented knowledge deficits (adding frequencies of errors and answer option:"I do not know"). For other questions, error rates added to the "I do not know" option were below $40 \%$.

In the group of nurses, question 1 received a higher frequency of errors (68.7\%) than in the"I do not know" option (12.5\%), which shows that $81.2 \%$ of respondents have knowledge deficits. The second most deficient in knowledge of the category was question 10 , where, although only $18.7 \%$ had failed the question, $56.3 \%$ indicated the "I do not know" option, which generated a lack of knowledge for $75 \%$ of the nurses. The third question with the highest frequency of errors was question 7 , where $62.5 \%$ of the respondents made a mistake, and none of them pointed to the "I do not know" option. The fourth question was number 11, where the sum of wrong answers and the "I do not know" option totaled $56.2 \%$. The fifth question with the greatest deficit of knowledge was number 2 , where $37.5 \%$ of the nurses missed the answer and $6.2 \%$ (corresponding to 1 respondent) indicated the "do not know" option, totaling $43.7 \%$ of professionals with a lack of knowledge about the nursing team's behavior regarding the presence of bleeding in MFW. For the other questions, the error frequencies added to the "do not know" option were below $40 \%$.

Table 3 - Associations between scores means in the test of knowledge and sociodemographic and educational variables, Passos, Minas Gerais, Brazil, 2015

\begin{tabular}{|c|c|c|c|c|}
\hline Characteristics & & Scores mean in the test & Standard Deviation & $\mathbf{p}^{*}$ \\
\hline \multirow[t]{2}{*}{ Gender } & Female & 6.2 & 2.3 & \multirow{2}{*}{0.73} \\
\hline & Male & 6.7 & 1.5 & \\
\hline \multirow[t]{4}{*}{ Marital Status } & Single & 6.3 & 2.3 & \multirow{4}{*}{0.62} \\
\hline & Married & 6.1 & 2.1 & \\
\hline & Divorced & 5.0 & 4.2 & \\
\hline & Stable Union & 8.0 & 2.8 & \\
\hline \multirow[t]{4}{*}{ Work Field } & Inpatient Unit & 6.3 & 2.5 & \multirow{4}{*}{0.56} \\
\hline & Chemotherapy & 6.6 & 1.6 & \\
\hline & Radiotherapy & 4.0 & - & \\
\hline & Ambulatory & 4.0 & - & \\
\hline \multirow[t]{2}{*}{ Profession } & Nursing Tech. & 5.8 & 2.5 & \multirow{2}{*}{0.17} \\
\hline & Nurse & 6.8 & 1.9 & \\
\hline \multirow[t]{2}{*}{ Another Academic Training } & No & 6.5 & 2.1 & \multirow{2}{*}{0.10} \\
\hline & Yes & 4.8 & 2.7 & \\
\hline \multirow[t]{2}{*}{ Wounds Training } & No & 6.4 & 2.0 & \multirow{2}{*}{0.57} \\
\hline & Yes & 5.9 & 2.8 & \\
\hline \multirow[t]{2}{*}{ Participation in Events about Wounds in the Last 5 years } & Yes & 6.1 & 2.5 & \multirow[b]{2}{*}{0.85} \\
\hline & No & 6.3 & 2.1 & \\
\hline
\end{tabular}

Note: * $p$-Descriptive level of the Student's t-Test. 
Nonetheless, considering that 16 nurses answered $176(16 \mathrm{x}$ 11) questions and obtained 109 correct answers, the correct rate was $61.9 \%$ for the group. In the same way for the nursing technicians, 21 professionals answered 231 questions and obtained 121 correct answers, resulting in a rate of $52.4 \%$.

Considering the group as a single team, 37 professionals answered 407 questions with 230 scores, which meant a success rate of $56.5 \%$.

However, for the answers to the questionnaire that evaluated the knowledge among technicians and nurses, there was no statistically significant difference between the answers, except for question number 10. This question was the fifth most frequent question among nursing technicians who understood the second question of the highest proportion of errors among the group of nurses.

The results of the associations between knowledge test scores and sociodemographic and educational variables are presented in Table 3 and Figure 1.

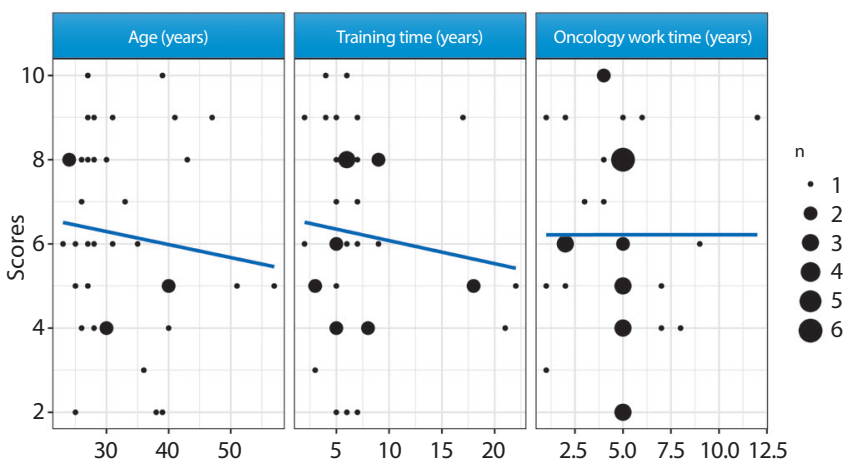

Figure 1 - Correlations between means of success in the test of knowledge and age (1), Training time (2) and Work time in oncology (3), Passos, Minas Gerais, Brazil, 2015

Table 3 shows the absence of statistically significant associations. Figure 1 shows the scatter plots about the correlations between the means of success of the knowledge test and the continuous variables, such as age, training time and team performance time in oncology.

According to the graphs in Figure 1, no correlation was found between age $(-0.031[\mathrm{Cl}-0.126-0.064], \mathrm{p}=0.51)$, training time $(-0.055[\mathrm{Cl}-0.208-0.099], \mathrm{p}=0.47)$ and oncology work time $(0.173$ $[\mathrm{Cl}-0.352-0.352], \mathrm{p}=0.99)$.

\section{DISCUSSION}

The present study aimed to evaluate the knowledge of nursing team members of a cancer hospital on MFW care and revealed a lack of knowledge of the team regarding fundamental aspects in the management of these lesions. In spite of participants' mean oncology work time, approximately five years, and acquisition of knowledge about wounds through participation in events related to the topic, nurses presented a proportion of correct answers above $80 \%$ in only five (question 4, 5,6,7 and 8) of the 11 evaluated questions. Nursing technicians presented scores above $70 \%$ on three questions $(4,6,9)$.

Considering the "specific technical knowledge of dressing practice" dimension, it is important to note that MFW is a chronic wound that, being cancer devoid of active treatment against the disease, will progress due to the development and degeneration of the tumor mass. Furthermore, patients and relatives will live with this wound throughout the life of the patient and home care will be part of the daily routine ${ }^{(2,6-8,11)}$. At some point, family members will need to use gloves for safer handling of the wound during dressing, as these wounds evolve in size, depth, and amount of necrotic tissue, odor, bleeding, and exudate $\mathrm{e}^{(2,12-14,22)}$. Thus, using the clean technique, procedure gloves will be indicated ${ }^{(22)}$. A question that dealt with the use clean technique use in home care with MFW obtained the highest frequency of knowledge deficit in the two professional categories.

Odor control was another question in which the study population presented knowledge deficits. Odor control in MFW is fundamental to patients' quality of life, observing in practice of care that they experience social isolation, depression, shame, embarrassment, and lack of appetite when they have fetid injuries. There are several products available for odor control, such as those based on silver, iodine, honey, antiseptics and topical antibiotics ${ }^{(2,6,21)}$. The metronidazole solution has been recommended in clinical practice for MFW odor control, observing positive results ${ }^{(2,23)}$.

Still considering the "specific technical knowledge of dressing practice" dimension, a question that dealt with the choice of coverings that stimulate healing, was the third question with the highest frequency of errors in both groups, added to the answers"I do not know" in both groups. Products of this nature are theoretically contraindicated for MFW by favoring the growth of cells at the tumor site. One of the products mentioned in the questionnaire contains Essential Fatty Acids (EFA) in their composition, which are known to be a cell growth stimulator by angiogenesis, which causes the proliferation of new blood vessels in the wound bed; undesirable stimulus to the wound bed with presence of malignant cells ${ }^{(14,21)}$. Respondents were expected to signal the statement that AGE should not be used in MFW as a true alternative. In the "nurses" category, the sum of the errors for this question (43.7\%) with the "I do not know" answer (12.5\%) reports that $56.2 \%$ of nurses have knowledge deficits. Similar deficit was noted in the "nursing technicians" category, where 19\% erred and $43.8 \%$ did not know how to respond, totaling a deficit of $61.9 \%$.

The conduct to be taken by the nursing team in case of MFW bleeding was the fourth question with the highest frequency of errors between groups. It is verified that the nurses have a deficit of $43.7 \%$ of knowledge, considering that $37.5 \%$ erred and $6.2 \%$ indicated the option "I do not know". Higher results were found among nursing technicians $(52.4 \%+4.7 \%$ respectively, totaling $=57.1 \%$ of deficit).

Research on MFW signs and symptoms control is scarce in the world literature. Nonetheless, the data in the present study are in agreement with the few existing literature. Odor and exudate of these wounds are referred to as the most distressing signs and symptoms for patients and family members ${ }^{(2,4,12-13)}$. Patients report that they would live better with pain than with the odor and exudate of their wounds. And for them, bleeding is the symptom that most frighten them ${ }^{(2,8)}$. On the other hand, nurses who experience care with this type of patient pointed out the difficulty in controlling odor, in preventing, minimizing or controlling bleeding, and doubts in choosing the most appropriate topical coverage as their greatest difficulties in performing patient dressings affected by MFW(4,7-8,10,16,19). 
A study with Brazilian nurses who, in their daily lives, dealt with outpatients, performing dressings on MFW due to breast cancer, revealed that they denominated their practices as a "penalizing routine", recognizing the disfiguration of the body and self-esteem caused by the wound. They called their performance a "challenging and frustrating care", even though they demonstrated a solidary interaction with their clientele. The reality imposed by the incurability of cancer, stating that the wound would not heal was the main factor of frustration for these nurses ${ }^{(19)}$.

An important literature review on $\mathrm{MFW}^{(4)}$ emphasized that the nurse professional is responsible for establishing an effective communication whose crucial element is the bonding and trust relationship between patients and the nursing team. There are nurses who feel uncomfortable in dealing with patients affected by this type of wound, especially when it is in a more advanced stage and the appearance of tumor tissue in frank degeneration predominates ${ }^{(6,8,19)}$.

In fact, MFW progress to a malignant evolution of necrosis, putrefaction, and involvement of the integumentary tissue ${ }^{(2,6,14,21)}$. In this sense, the knowledge related to the "theoretical concepts about the development and progression of wounds" dimension is relevant because they base the practice of nursing care and impel new forms of interventions.

Specific characteristics of the degenerative evolution of MFW determined the elaboration of a classification system similar to that existing for the classification of pressure injuries. It is a classificatory system developed by American researchers and disseminated to the scientific community in $1999^{(24)}$. In Brazil, after translation and free adaptation, such classification system was published in specific literature on oncology nursing, in 2005(25), and adopted by INCA. This is a training center for human resources, this information was multiplied in classes, technical visits and clinical protocols as of $2009^{(14)}$. Even so, the instrument is little known in our environment, mainly by the nurses, as pointed out in the study presented here.

Disregarding 100\% correct answers about the cause of myiasis in the wounds, the question that investigated the knowledge about the purpose of dressing in signs and symptoms control of MFW (question 4) was the one that obtained the highest proportion of right answers in both groups (87.5\% in the group of nurses and $71.4 \%$ in nursing technicians).

MFW healing is not usually the goal in performing the dressings for this type of wounds $s^{(2,6,14,21)}$. Nevertheless, the study showed that $62.5 \%$ of nurses answered this question, versus 33.4 of nursing technicians.

When investigated the correlation between age, training and oncology work time, important variables, when thinking about Permanent Education of health professionals, had no significant relation with the number of correct answers.

The expected results for this research study were not obtained. Professionals demonstrated a significant lack of knowledge about the clean versus sterile technique use at home - an important issue for family counseling; odor and bleeding control; important interventions that impact on the well-being of patients affected by MFW; non-stimulatory healing coverings use that may lead to increased tumor cell numbers in the wound bed when the tumor is in the malignant proliferation phase rather than degeneration.
MFW theme is complex and little explored in the activities of research and education in cancer nursing in our country. Researchers in the United States argue that the low prevalence of these lesions may be a factor that explains the lack of research and more assertive treatment guidelines ${ }^{(6)}$. A Brazilian study that investigated the scientific production of "chronic wounds" in dissertations and Brazilian theses covering the period from 2001 to 2010, had as sample 43 studies, $20.9 \%$ of which were developed in São Paulo State ${ }^{(26)}$. In this study, the researchers pointed to the MFW as "lesions of lesser interest", counting only one study that comprised $2 \%$ of the study sample.

A recent qualitative research that investigated aspects related to the training of resident nurses in relation to the facilitated aspects and difficulties in relation to care for cancer patients involved 34 professionals ${ }^{(27)}$. When asked if they received any type of training to care for this clientele, $56 \%$ answered that they did not and $44 \%$ answered yes, the most cited contents being: nursing care, chemotherapy, breast cancer, cervix and prostate cancer. It was not possible to know if the MFW was approached in the context of these themes. The data suggest that nurses lack knowledge and that educational activities specifically for the "MFW" theme are desirable both for nursing teams members that are active in the practical field, as well as for those in training process.

Understanding the role of nurses in leading nursing education and nursing education processes, the results of the study presented here are worrisome and require the attention of nurses responsible for educational development in health and educational institutions. They are at the forefront of updating the nursing team in evidence-based practices and practices for a subject with growing social demand but still under-researched, debated and painful for patients and professionals who follow them ${ }^{(2,13,19)}$.

\section{Study limitations}

The study contributes to the approach of an impact problem in daily care practice in institutions and care units for cancer patients, increasing morbidity in the country. Their results reinforce those available in the literature. Nevertheless, it presents limitations regarding the small sample size composed of nursing professionals from a single hospital, even if it is a regional reference for cancer care.

The reduced sample did not allow the analysis of the questionnaire by the Item Response Theory (IRT), in which situation it would be possible to investigate the ownership of each item of the questionnaire in an individualized way, a very opportune fact for a subject so little explored. For the same reason, it was not possible to use statistical tests with a higher level of disaggregation, such as regression tests.

\section{Contributions to Nursing, Health, and Public Policy}

Although the study was designed to evaluate the knowledge of the nursing team working in a specialized oncology hospital, where MFW are more present phenomena than in general hospitals, its results are similar to those obtained in general hospitals ${ }^{(10)}$, community and care network ${ }^{(16)}$. This finding implies the need to develop teaching strategies and technical training in institutions specialized in cancer care.

The study contributes with notes to nursing in the specialty of oncology in general, but specifically to the development of 
continuing education programs in the institution where it was developed.

The contribution of the present study also occurs to include the professional category of the nursing technician and to compare their knowledge to those of the nurses. In the absence of statistically significant differences in the knowledge presented by the two professional categories, the study identifies the imperative need of urgent Permanent Education for all professionals of the team, particularly of nurses, who are responsible for the training, updating and training of nursing technicians.

\section{CONCLUSION}

In a sample composed of 37 nursing professionals working in a hospital specialized in cancer treatment, they answered a questionnaire about the nursing care provided to patients affected by MFW. The proportion of correct answers was $56.5 \%$, with no statistically significant difference between the groups and between the professional qualification levels.

The main errors presented concern, respectively, the clean technique use in home care, measures for odor control, choice of coverages and interventions of the team to control bleeding. Concepts about healing and classification of this type of wound are also little known among the studied sample.

\section{ACKNOWLEDGMENT}

A special thanks to Leila Aparecida Muniz Cardoso, Pauline Teixeira Stella and Washington dos Reis for their collaboration in the data collection phase of the study.

\section{REFERENCES}

1. Ministério da Saúde (BR). Portaria n. 874, de 16 de maio de 2013. Institui a Política Nacional para a Prevenção e Controle do Câncer na Rede de Atenção à Saúde das Pessoas com Doenças Crônicas no âmbito do Sistema Único de Saúde [Internet]. Brasília; 2013 [cited 2016 Apr 29 ]. Available from: http://bvsms.saude.gov.br/bvs/saudelegis/gm/2013/prt0874_16_05_2013.html

2. Ferrell BR, Coyle N, Paice JA. Oxford Text book of Palliative Nursing. 4th ed. New York: Oxford; 2015.

3. Hermes HR, Lamarca ICA. Cuidados Paliativos: uma abordagem a partir das categorias profissionais de saúde. Ciênc Saúde Colet. 2013;18(9):2577-88. doi: 10.1590/S1413-81232013000900012

4. Taylor C. Malignant fungating wounds: a review of the patient and nurse experience. Br J Community Nurs. 2013;16(Suppl 12):S16-22. doi: 10.12968/bjcn.2011.16.Sup12.S16

5. Vaquer LM. Manejo de las ulceras cutaneas de origen tumoral: cutanides. Rev Int Grupos Invest Oncol [Internet]. 2013 [cited 2016 Apr 29];1(2):52-9. Available from: https://www.elsevier.es/ es-revista-regio-revista-internacional-grupos-investigacion-339-pdf-X2253645012578954

6. Grocott P, Gethin G, Probst S. Malignant wound management in advanced illness: new insights. Curr Opin Suport Palliat Care. 2013;7(1):1015. doi: 10.1097/SPC.0b013e32835c0482

7. Fromantin I, Watson S, Baffie A, Rivat A, Falcou MC, Kriegel I, et al. A prospective, descriptive cohort study of malignant wound characteristics and wound care strategies in patients with breast cancer. Ostomy Wound Manage. 2014;60(6):38-48.

8. Alexander SJ. An intense and unforgettable experience: the lived experience of malignant wounds from the perspectives of patients, caregivers and nurses. Int Wound J. 2010;7(6):456-65. doi: 10.1111/j.1742-481X.2010.00715.x

9. Tamai N, Akase T, Minematsu T, Higashi K, Toida T, Igarashi K, et al. Association between components of exudates and periwound moisture-associated dermatitis in breast cancer patients with malignant fungating wounds. Biol Res Nurs. 2016;18(2):199-206. doi: $0.1177 / 1099800415594452$

10. Probst S, Arber A, Faithfull S. Malignant fungating wounds: a survey of nurses' clinical practice in Switzerland. Eur J Oncol Nurs. 2009;13(4):295-8. doi: doi: 10.1016/j.ejon.2009.03.008

11. Probst S, Arber A, Trojan A, Faithfull S. Caring for a loved one with a malignant fungating wound. Support Care Cancer. 2012;20(12):3065-70. doi: 10.1007/s00520-012-1430-y

12. Lo SF, Hayter M, Hu WY, Tai CY, Hsu MY, Li YF. Symptom burden and quality of life in patients with malignant fuganting wounds. J Adv Nurs. 2012;68(6):1312-21. doi: 10.1111/j.1365-2648.2011.05839.x

13. Gibson S, Green J. Review of patients' experiences with fungating wounds and associated quality of life. J Wound Care. 2013;22(5): 265-6, 268, 270-2. doi: 10.12968/jowc.2013.22.5.265

14. Ministério da Saúde (BR). Secretaria de Atenção à Saúde. Instituto Nacional de Câncer (INCA). Coordenação de Assistência. Tratamento e controle de feridas tumorais e úlceras por pressão no câncer avançado [Internet]. Rio de Janeiro: INCA; 2009. [cited 2016 May 03]; Available from: http://bvsms.saude.gov.br/bvs/publicacoes/inca/Feridas_Tumorais.pdf

15. Lisboa IND, Valença MP. Caracterização de pacientes com feridas neoplásicas. Estima. 2016;14(1):21-8. doi: 10.5327/ Z1806-3144201600010004

16. Azevedo IC, Costa RKS, Holanda CSM, Salvetti MG, Torres GV. Conhecimento de enfermeiros da estratégia saúde da família sobre avaliação e tratamento de feridas oncológicas. Rev Bras Cancerol [Internet]. 2014 [cited 2016 May 03];60(2):119-27. Available from: https://rbc.inca.gov. br/site/arquivos/n_60/v02/pdf/05-artigo-conhecimento-de-enfermeiros-da-estrategia-saude-da-familia-sobre-avaliacao-e-tratamento-de- 
feridas-oncologicas.pdf

17. Santos SN, Martins MC, Chammas R. Classificação e nomenclatura anátomo patológica de tumores. In: Saito RF, Lana MVG, Medrano RFV, Chammas R, editores. Fundamentos de oncologia molecular. São Paulo: Atheneu, 2015. p. 15-35.

18. Ministério da Saúde (BR). Secretaria de Atenção à Saúde. Instituto Nacional de Câncer. Coordenação de Prevenção e Vigilância. Estimativa 2018/2019: Incidência de Câncer no Brasil [Internet]. Rio de Janeiro: INCA; 2018 [cited 2018 Jul 26]; Available from: http://www.inca.gov.br/ estimativa/2018/introducao.asp

19. Firmino F, Alcântara LFFL. Enfermeiras no atendimento ambulatorial a mulheres com feridas neoplásicas malignas nas mamas. Rev Rene. 2014;15(2):298-307. doi: 10.15253/2175-6783.2014000200015

20. Ministério da Saúde (BR). Resolução CNS, no 466 de 12 de dezembro de 2012. Aprova as diretrizes e normas regulamentadoras de pesquisa envolvendo seres humanos [Internet]. Brasília; 2013 [cited 2016 May 03]. Available from: http://conselho.saude.gov.br/resolucoes/2012/ Reso466.pdf

21. Matsubara MGS. Feridas neoplásicas. In: Matsubara MGS, Villela D, Hashimoto SY, Reis HCS, Saconato RA, Denardi U, organizadores. Feridas e estomas em oncologia: uma abordagem interdisciplinar. São Paulo: Lemar; 2011. p. 33-46.

22. Ferreira AM, Andrade D. Integrative review of the clean and sterile technique: agreement and disagreement in the execution of dressing. Acta Paul Enferm. 2008;21(1):117-21. doi: 10.1590/S0103-21002008000100019

23. Haisfield-Wolfe ME, Rund C. Malignant cutaneous wounds; developing education for hospice, oncology and wound care nurses. Int J Palliat Nurs. 2002;8(2):57-66. doi: 10.12968/ijpn.2002.8.2.10240

24. Castro DLV, Santos VLCG. Controle do odor de feridas com metronidazol: revisão sistemática. Rev Esc Enferm USP. 2015;49(5):851-6. doi: $10.1590 /$ S0080-623420150000500021

25. Firmino F, Alcântara LFFL. Enfermeiras no atendimento ambulatorial a mulheres com feridas neoplásicas malignas nas mamas. Rev Rene. 2014;15(2):298-307. doi: 10.15253/2175-6783.2014000200015

26. Brito KKG, Sousa MJ, Sousa ATO, Meneses LBA, Oliveira SHS, Soares MJGO. Chronic injuries: nursing approach in the post graduate scientific production. J Nurs UFPE On Line. 2013;7(2):414-21. doi: 10.5205/reuol.3073-24791-1-LE.0702201312

27. Lins FG, Souza SR. Training of nurses for care in oncology. J Nurs UFPE On Line. 2018;12(1):66-74. doi: 10.5205/1981-8963-v12i01a22652p66-74-2018 